\title{
除草剤アロキシジムおよび分解物の残留分析法
}

\author{
小野成男, 遠山典宏, 杉岡克己 \\ 時枝正則，野村修三，塚田松吾 \\ 日本曹達（株）ファインケミカル研究所
}

(昭和 55 年 6 月 10 日受理)

\section{Residue Analysis of Alloxydim-sodium and Its Degradation Products}

\author{
Shigeo Ono, Norihiro Toyama, Katsumi Sugroka, Masanori Tokieda, \\ Osami Nomura and Shogo Tsukada \\ Fine Chemicals Research Laboratory, Nippon Soda Co., Ltd., \\ Takada, Odawara, Kanagawa 250-02, Japan
}

\begin{abstract}
Residue analysis of alloxydim-sodium[sodium salt of 2-(1-allyloxyaminobutylidene)5,5-dimethyl-4-methoxycarbonyl cyclohexane-1,3-dione) and its degraded compounds in crops and soils were investigated. As a result of the experiments by three different analytical methods, high performance liquid chromatography (HPLC), gas chromatography (GC) and ultra-violet spectrophotometry (UV), the HPLC method was found to be most suitable. Alloxydim and degraded compounds in samples were extracted with methanol. These compounds in an aqueous methanol solution were extracted separately with $n$-hexane and methylene chloride. Alloxydim in $n$-hexane was cleaned up by liquid-liquid separation. Degraded compounds in methylene chloride were subjected to thin layer chromatography. Each compound was determined by the HPLC method. The lower limit of detection for each compound was $0.01 \mathrm{ppm}$. Recoveries of alloxydim were $86-93 \%$ in crops and $85-91 \%$ in soils, and those of degraded compounds were $75-92 \%$ in crops and $87-92 \%$ in soils.
\end{abstract}

\section{緒言}

選択性除草剤アロキシジム [sodium salt of 2-(1-allyloxyaminobutylidene-5, 5 -dimethyl-4-methoxycarbonylcyclohexane-1,3-dione, 以下 ADS と略す] およびこの 分解物である CM-I [2-(1-aminobutylidene)-5, 5-dimethyl-4-methoxycarbonylcyclohexane-1, 3-dione], CMII [methyl 6, 6-dimethyl-2-propyl-4-oxo-4, 5, 6, 7tetrahydrobenzoxazole-5-carboxylate] および CM-III [methyl 6,6-dimethyl-2-propyl-4-oxo-4, 5, 6, 7-tetrahydrobenzoxazole-7-carboxylate] の環境中での残留量を 把握するために分析法を検討した.

$\mathrm{ADS}$ の遊離体 $\mathrm{AD}$ およびこれら分解物はいずれも紫 外部に吸収スペクトルを有するため, 紫外吸光光度法や
紫外線検出器付高速液体クロマトグラフ法での定量が可 能であった. 同時に電子捕獲型検出器付きガスクロマト グラフ法による定量法についても検討した. ADS は各 種作物に使用されるため, 抽出抢よびクリーンアッブ操 作はなるべく画一的な方法を考えた.

この結果, 高速液体クロマトグラフ法および紫外吸光 光度法ではこれら 4 化合物の定量が可能であった. ガス クロマトグラフ法では誘導体を合成することにより， $\mathrm{AD}$ および CM-I の定量が可能であった. 紫外吸光光 度法は作物, 土塞の場合, 妨害を受けやすく主として水 系の残留分析に適用可能であったが, 高速液体クロマト グラフ法およびガスクロマトグラフ法は各種作物および 土塨の残留分析に十分満足できる結果が得られた. 


\section{分 析 法}

\section{1. 高速液体クロマトグラフ法}

1) 試薬および機器

試薬類は特級品をとのまま使用した．ただし，高速液 体クロマトグラフィーの溶離液に使用する場合は, ガラ ス器具を用いて蒸留した。

ADS 精製品：原体を少量のメチルアルコールに溶か し，二塩化エタンで希釈する。メチルアルコールを 留去し析出した ADS を濾別する. ADS を少量の メチルエチルケトンで洗浄する. 純度 $99 \%$ 以上, 融点 $185.5^{\circ} \mathrm{C}$ (分解)

CM-I 精製品：精製した 2-butyloyl-5,5-dimethyl-4methoxycarbonylcyclohexane-1,3-dione とアンモ二 アの縮合により合成. 純度 $99 \%$ 以上， $n_{\mathrm{D}}^{23.5} 1.5406$ CM-II 精製品：ADをェチルアルコール中で加温して 合成, カラムクロマトグラフ精製. 純度 $99 \%$ 以上, $n_{\mathrm{D}}^{23.5} 1.5035$

CM-III 精製品： AD をェチルアルコール中で加温し て合成し，オキシム体に誘導して CM-II と分離す る. 加水分解後, カラムクロマトグラフ精製. 純度 $99 \%$ 以上, 融点 $82-83^{\circ} \mathrm{C}$

これら化合物の物性值はすでに報告1)されている. 高速液体クロマトグラフ：バリアン製 4200 型

同検出器：バリアン製紫外分光光度計

2）高速液体クロマトグラフィーの条件

分離管：内径 $2 \mathrm{~mm}$, 長さ $50 \mathrm{~cm}$ ，ステンレス製

充填剂: マイクロパック SI-10

溶離液：0.5\%メチルアルコール/塩化メチレン $(\mathrm{AD}$, CM-II, III 定量用), $1.5 \%$ メルアルコール/塩化 メチレン (CM-I 定量用)

流速: $0.5 \mathrm{ml} / \mathrm{min}$

検出条件: 波長 $254 \mathrm{~nm}$, フローセル容量 $8 \mu \mathrm{l}$, 室温 記録紙速度： $5 \mathrm{~mm} / \mathrm{min}$

3）検量線の作成

(1) 土塞 $500 \mathrm{ppm}$ の $\mathrm{ADS}$ 水溶液 1，2，4 および $6 \mathrm{ml}$ を採取し, $0.1 \mathrm{~N}$ 塩酸 $20 \mathrm{ml}$ を加えて弱酸性とし, $20 \mathrm{ml}$ のへキサンを加えて振とうし抽出する. さらに 2 回抽出をくり返す. 抽出したへキサン溶液を合わせて脱 水し, 溶媒を減圧留去する. 乾固物を塩化メチンンに溶 かし $100 \mathrm{ml}$ メスフラスコに移し，5，10，20 および 30 ppm の塩化メチレン溶液を調製する.この溶液 $10 \mu \mathrm{l}$ を 高速液体クロマトグラフに注入する．ピークの高さを測 定し検量線を作成する.

CM-I，II および III はそれぞれ，5，10，15 および
$20 \mathrm{ppm}$ のクロロホルム溶液を調製し，10 $\mu \mathrm{l}$ を高速液体 クロマトグラフに注入し，ピーク高さを測定し検量線を 作成する.

(2) 作物 $\mathrm{ADS}$ は土塞の場合と同様に作成する.CMI, II および III は，それぞれ $500 \mathrm{ppm}$ のクロロホルム 溶液 1，2，3 および $4 \mathrm{ml}$ を $10 \mathrm{ml}$ のメスフラスコ中 に採取し，クロロホルムで定容とする．この溶液 $100 \mu \mathrm{l}$ を薄層プレート（メルク社製シリカゲルアルミシート， Art. 5554) に塗布し溶媒（クロロホルム/アセトン=8/2) で $10 \mathrm{~cm}$ ほど展開する.とれぞれの $R f$ の部分を切り 取り,メタノール $25 \mathrm{ml}$ に 10 分間浸漬し抽出する. メ タノール抽出液を減圧濃縮し乾固する. 乾固物を正確に クロロホルム $1.0 \mathrm{ml}$ に溶解し, この溶液 $10 \mu \mathrm{l}$ を高速 液体クロマトグラフに注入し検量線を作成する。

4) 分析操作

(1) 土塞 乾土換算 $30 \mathrm{~g}$ の土壌を $500 \mathrm{ml}$ の三角フ ラスコ中に入れ， $0.1 \mathrm{~N}$ 塩化アンモニウム溶液 $20 \mathrm{ml}$, メチルアルコール $80 \mathrm{ml}$ を加えて 10 分間振とうする. 内容物を遠心分離 $(8,000 \mathrm{rpm})$ を行ない, 上澄液を滤過 する. 残椬を再び $0.1 \mathrm{~N}$ 塩化アンモニウム溶液 $20 \mathrm{ml}$, メチルアルコール $80 \mathrm{ml}$ を加えて 10 分間振とうする. 同様に遠心分離を行ない, 吸引濾過する. 残椬を $0.1 \mathrm{~N}$ 塩化アンモニウム溶液 $120 \mathrm{ml}$ で洗浄し吸引濾過する. 濾液を合わせ塩化ナトリウム $2 \mathrm{~g}$, 濃塩酸 $3 \mathrm{ml}$ を加え て, $100 \mathrm{ml}$ のへキサンで 3 回振とう抽出する.〔へキサ ン抽出後の水層は CM-I, II および III の分析に供す る]. $0.1 \mathrm{~N}$ 水酸化ナトリウム溶液 $100 \mathrm{ml}$ を一キサン抽 出液に加え 5 分間振とうして $\mathrm{AD}$ をアルカリ層に移す. この操作をくり返す．抽出したアルカリ溶液を合わせて クロロホルム $50 \mathrm{ml}$ で 3 分間振とうし洗浄する. クロ ロホルム層は捨てる．アルカリ溶液をへキサン $50 \mathrm{ml}$ 3 分間振とう洗浄する. ヘキサン層は捨てる. アルカリ 溶液に濃塩酸 $10 \mathrm{ml}$ を加え酸性とし, へキサン $100 \mathrm{ml}$ を加えて 10 分間振とう抽出する. この操作をさらに 2 回くり返す. ヘキサン層を合わせ蒸留水 $50 \mathrm{ml}$ で洗浄後 脱水し，減圧濃縮し，注意して乾固する．乾固物を正確 に $1.0 \mathrm{ml}$ のクロロホルムに溶解し，この液 $10 \mu \mathrm{l}$ を高 速液体クロマトグラフに注入し，検量線から ADS の含 有量を求める。

[CM-I, II および III の定量]

ヘキサン抽出後のメチルアルコール溶液に $100 \mathrm{ml}$ の 塩化メチレンを加え 5 分間振とうし，CM-I， II および III を抽出する. この抽出操作をくり返す，塩化メチレ ン層を合わせ， $0.1 \mathrm{~N}$ 水酸化ナトリウム溶液 $50 \mathrm{ml}$ で 1 回, 蒸留水 $50 \mathrm{ml}$ で 1 回それぞれ洗浄し, 洗浄液は捨て 


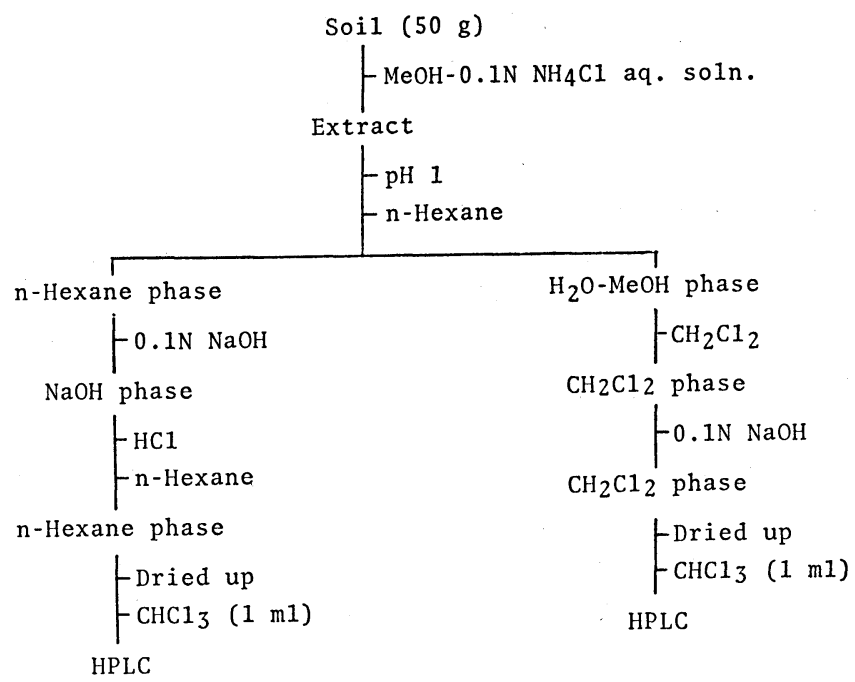

Fig. 1 Flow diagram of analytical method for residues in soil.

Operating conditions of HPLC; Detector: UV (254 nm), Column: Micropak Si-10, $\phi 2 \mathrm{~mm} \times$ $50 \mathrm{~cm}$, Mobile phase: $0.5 \%$ methanol/methylene chloride (for $\mathrm{AD}, \mathrm{CM}-\mathrm{II}$, III), $1.5 \%$ methanol/methylene chloride (for $\mathrm{CM}-\mathrm{I}$ ), Flow rate: $0.5 \mathrm{ml} / \mathrm{min}$.

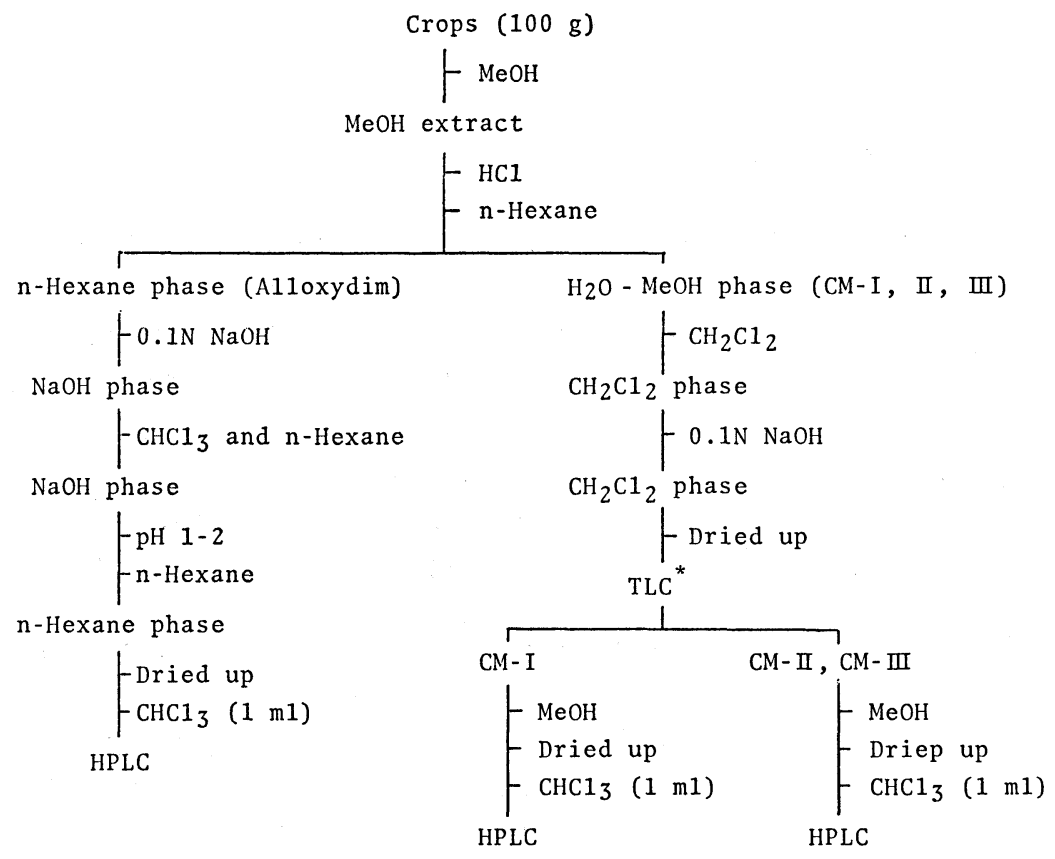

Fig. 2 Flow diagram of analytical method for residues in crops.

* tlc condition

Merck Art 5554®

Chloroform: Acetone (8:2)

る. 塩化メチレン溶液を脱水後, 減圧濃縮し乾固する. 乾固物を正確に $1.0 \mathrm{ml}$ のクロロホルムに溶解し，この 液 $10 \mu \mathrm{l}$ を高速液体クロマトグラフに注入し, 検量線か
ら, CM-I, II および III を定量する. Fig. 1 に操作法 の概要を示す。

(2) 作物 細切りにした野菜 $100 \mathrm{~g}$ をブレンダー中に 
科取し，メチルアルコール $100 \mathrm{ml}$ を加えて 10 分間ブ レンドする，スラリーを遠心分離 $(8,000 \mathrm{rpm})$ し，吸引 滤過後, 残渣を $50 \mathrm{ml}$ のメチルアルコールで洗浄し，こ の液も濾液に合わせる. 水 $80 \mathrm{ml}$, 塩化ナトリウム約 $5 \mathrm{~g}$ と塩酸 $3 \mathrm{ml}$ を加え攪拌後, 数分間放置する. 溶液を遠 心分離し，濾過する．濾液に $100 \mathrm{ml}$ のへキサン家加光， 5 分間振とうし $\mathrm{AD}$ を抽出する. この操作をさらに 2 回くり返す. 〔抽出後の水層は CM-I, II および III の 定量に供する]。 $\mathrm{AD}$ の定量は土㙵の場合々同様に操作 する. 代謝物の定量は, 一キサン抽出後の水層を $100 \mathrm{ml}$ の塩化メチンンで 2 回抽出し 洗浄後減圧濃縮し 乾固す る. 乾固物を塩化メチレンに溶解し, 薄層プレートに全 量塗布して, 以下検量線の作成方法に従って操作し含有 量を求める. Fig. 2 に操作法の概要を示す.

\section{2. ガスクロマトグラフ法}

1）試薬抢よび機器

試薬類は特級品をそのまま使用した。ただし，四塩化 炭素は特級品をガラス器具を用いて蒸留した。

$\mathrm{ADS}$ および CM-I 精製品は高速液体クロマトグラフ 法の場合と同様である.

ガスクロマトグラフ：島津製 GC5A 型

同検出器：電子捕獲型 $\left({ }^{63} \mathrm{Ni}\right.$ 使用)

2）ガスクロマトグラフィーの条件

分離管：内径 $3 \mathrm{~mm}$ ，長さ $1 \mathrm{~m}$ ，ガラス製

充填浏: $2 \% \mathrm{DC}-11 /$ クロモソルブ $\mathrm{G}, \mathrm{AW}, \mathrm{DMCS}$,

60 80 メッシュ

温度: 注入部 $210^{\circ} \mathrm{C}$, カラム $180^{\circ} \mathrm{C}$, 検出器 $250^{\circ} \mathrm{C}$ キャリヤーガス：高純度窒素, $0.3 \mathrm{~kg} / \mathrm{cm}^{2}(\mathrm{AD}), 0.6$

$\mathrm{kg} / \mathrm{cm}^{2}(\mathrm{CM}-\mathrm{I})$

記録紙速度：10 mm/min

3）検量線の作成

$5 \mathrm{ppm}$ の $\mathrm{ADS}$ 水溶液 1，2，3，4 および $5 \mathrm{ml}$ を $100 \mathrm{ml}$ の分液漏斗に採取し, $0.1 \mathrm{~N}$ 塩酸 $20 \mathrm{ml}$ を加㫕 てへキサン $20 \mathrm{ml}$ で 3 回振とう抽出する. へキサン層を 合わせ脱水し, 溶媒を減圧留去する. 乾固物を $5 \mathrm{ml}$ の 四塩化炭素に溶解し，N-クロロスクシンイミド約 $50 \mathrm{mg}$ と沸石を加え，10 分間加熱還流する，反応後溶媒を完 全に留去し, 乾固物を $25 \mathrm{ml}$ のへキサンに溶解し, 10 $\mathrm{ml}$ の $0.1 \mathrm{~N}$ 水酸化ナトリウム溶液, $10 \mathrm{ml}$ の $1 \mathrm{~N}$ 塩酸 および $30 \mathrm{ml}$ の蒸留水で順に洗浄する. 洗浄液は捨て る. 一キサン溶液を脱水し, 正確に $25 \mathrm{ml}$ とし, この溶 液 $2 \mu 1$ をガスクロマトグラフに注入し検量線を作成す る.

$500 \mathrm{ppm}$ の CM-I クロロホルム溶液 1，2，3，4 お よび $5 \mathrm{ml}$ を $10 \mathrm{ml}$ のメスフラスコ中に採取し, クロロ
ホルムで定容とする，それぞれの溶液 $100 \mu 1$ を薄層プ レート〔メルク製シリカゲルフルミシート，Art. 5554] に塗布し，溶媒（クロロホルム/アセトン =8/2）で展開 する. CM-I のバンドを切り取り, $50 \mathrm{ml}$ の分液漏斗中 に入れ, $25 \mathrm{ml}$ のクロロホルムで 2 回振とう抽出する. 抽 出液は濾過し隇圧で濃縮し，少量になったときに $25 \mathrm{ml}$ 共栓試験管に入れ乾固する. 乾固物は $2 \mathrm{ml} の$ のサン に溶解し， $0.2 \mathrm{ml}$ の無水トリフルオ口酶酸を加え密栓 し， 10 分間室温で放置する. $20 \mathrm{ml}$ の蒸留水を加光， 25 $\mathrm{ml}$ のへキサンで 2 回振とうし, CM-I 反応物をへキサ ン層へ移す。へキサン層を $10 \mathrm{ml}$ の $0.1 \mathrm{~N}$ 水酸化ナト リウム溶液および $10 \mathrm{ml}$ の蒸留水で順に洗浄する. へキ サン溶液を脱水し， $50 \mathrm{ml}$ として，この液 $2 \mu 1$ をガスク ロマトグラフに注入し検量線を作成する。

4) 分析操作

抽出拉よび液液分配の操作は高速液体クロマトグラフ 法の分析操作に従って行なう. 液液分配後, 検量線の作 成方法に従って操作する.

\section{3. 紫外吸収スペクトル法}

1) 試薬打よび機器

試薬類は特級品をそのまを使用した。

ADS および分解物精製品は高速液体クロマトグラフ 法の場合と同様である.

分光光度計：日立製 124 型

液体用セル：5cm 角形石英セル

2）検量線の作成

$500 \mathrm{ppm}$ の ADS 水溶液 10，20，30，40 および 50 $\mathrm{ml}$ を $100 \mathrm{ml}$ の分液漏斗に採取し， $1 \mathrm{~N}$ 塩酸 $1 \mathrm{ml}$ を加 えて $25 \mathrm{ml}$ のクロロホルムで 2 回振とう抽出する.ク口 ロホルム層を合わせ $100 \mathrm{ml}$ メスフラスコ中に移し，ク ロロホルムで定容とする．この溶液 $100 \mu 1$ を薄層プレ 一トに塗布し，溶媒（クロロホルム/アセトン=8/2）で 展開する. $\mathrm{AD}$ の $R f$ の部分を切り取り, $25 \mathrm{ml}$ の栓付 試験管中に入れ正確に $20 \mathrm{ml}$ のメチルアルコールを加え て薄層プレートの切片を浸漬し, 密栓して 10 分間放置 する. $1 \mathrm{~N}$ 水酸化ナトリウム溶液 $0.1 \mathrm{ml}$ を加え, 静か に混合し $5 \mathrm{~cm}$ 石英セルに移す. 対照にはブランクの薄 層プレートの切片を浸漬したメチルアルコール溶液を用 い，220 340 nm の領域の吸収スペクトルを測定する。 ベースライン法により検量線を作成する.

CM-I, II および III については，それぞれの $500 \mathrm{ppm}$ クロロホルム溶液 $1 ， 2 ， 3 ， 4$ 打よび $5 \mathrm{ml}$ を $10 \mathrm{ml}$ の メスフラスコ中に採取し，クロロホルムで定容とする. それぞれの溶液 $100 \mu 1$ を薄層プレートに塗布し，溶媒 （ベンゼン/酶酸エチル＝10/3）で展開する，以下:ADS 
の場合と同様に操作するが，水酸化ナトリウム溶液は添 加しない.

3）分析操作

抽出打よび液液分配の操作は高速液体クロマトグラフ 法の分析操作に従って行なう. 液液分配後, 検量線の作 成方法に従って操作する.

\section{実験}

\section{1. 紫外吸収スペクトル}

メチルアルコール中で各化合物の紫外吸収スペクトル を測定した結果, $\mathrm{AD}$ は 254, $285 \mathrm{~nm}, \mathrm{CM}-\mathrm{I}$ は 253, $289 \mathrm{~nm}, \mathrm{CM}-\mathrm{II}$ は $253 \mathrm{~nm}, \mathrm{CM}-\mathrm{III}$ は $248 \mathrm{~nm}$ にそれ ぞれ極大吸収を示すことがわかった． AD は有機溶媒中 では，ケト，エノール型構造による三つの吸収帯を有す るが, アルカリ溶液中ではエノール型構造を有するた め, $287 \mathrm{~nm}$ に一つの極大吸収を示す。このため ADSの 測定にはメチルアルコール溶液に $1 \mathrm{~N}$ 水酸化ナトリウム 溶液を $0.1 \mathrm{ml}$ 添加した。紫外吸収スペクトル法で測定 する場合妨害を受けやすいので，ベースライン法を採用 した．各化合物の分子吸光係数は Table 1 のとおりであ る.

\section{2. 高速液体クロマトグラフィーの条件}

検出器として䖝光光度計の利用を検討したが, 各化合 物ともそのままの形ではいずれも䖝光を発しなかった。 化合物の紫外吸収スペクトルの極大吸収波長はそれぞれ 少しずつ異なっているが，250 nm 付近に認められたの で固定波長の検出器でも使用できるように $254 \mathrm{~nm}$ を検 出波長とした。分離管充埧剂としてマイクロパック SI10, マイクロパック $\mathrm{CH}-10$, マイクロパック $\mathrm{CN}-10$ (い ずれもバリアンのパックドカラム）と日立ゲル \#3010, \# 3050 を用いてピークの形状, 感度および CM-II, III の分離を主として検討した結果，マイクロパック SI-10 が優れていた. 水系カラムで水・メチルアルコールを溶 離液とする場合， $\mathrm{AD}$ をメチルアルコールに溶解してお くと経時的に異性体の生成量が増加し，ピークが二つに 分かれることが認められた。 マイクロパック SI-10を充 塡戍とし, 溶離液に $0.5 \%$ メチルルコール/塩化メチ レンを用いた場合，各化合物の保持時間（分）は $\mathrm{AD}$ は 4.6, CM-I は 22.4, CM-II は 6.4, CM-III は 7.5 で CM-I がかなり遅れて溶出されることがわかったので， CM-I の溶離液としては 1.5\% メチルアルコール/塩化 メチレンとした。この場合，グラジェント溶出法も可能 であるが，一定組成の溶液で溶出させたほうが常行的に 分析する場合, 再現性や分析所要時間等に有利な点が多 かったので，グラジェント法は採用しなかった。この
Table 1 Molar extinction coefficient of AD \& CM-I, II, III.

\begin{tabular}{cccc}
\hline Compound & $\begin{array}{r}\lambda_{\max } \\
(\mathrm{nm})\end{array}$ & $\varepsilon$ & Solvent \\
\hline Alloxydim & 287 & $2.0 \times 10^{4}$ & dil. NaOH \\
CM-I & 253 & $1.5 \times 10^{4}$ & $\mathrm{MeOH}$ \\
& 289 & $1.6 \times 10^{4}$ & $\mathrm{MeOH}$ \\
CM-II & 253 & $7.2 \times 10^{3}$ & $\mathrm{MeOH}$ \\
CM-III & 248 & $7.2 \times 10^{3}$ & $\mathrm{MeOH}$ \\
\hline
\end{tabular}

CM-I の溶離液では CM-II と III の分離は不十分であ った. カラムはすべて室温状態とし温度の影響について はとくに検討しなかった. Table 2 に溶離液と各化合物 の保持時間を示した。

\section{3. 抽出溶媒の検討}

作物, 土塨からの抽出溶媒としてメチルアルコールを 使用した。メチルアルコールの代りにアセトンについて も検討したがとくに優れた利点は見いだせなかった。土 壌から各化合物を抽出する場合の溶媒について検討した 結果 Table 3 に示すように塩化アンモニウムとメチルア ルコールの混合溶媒が最も良好であったので採用した。

\section{4. クリーンアップの検討}

液液分配と薄層クロマトグラフィーによるクリーンフ ップを検討した。 カラムクロマトグラフィーは分析対象 物が多く，妨害成分も多い場合，条件の選定に長時間を 要することが予想されたので，とくに検討しなかった。 液液分配の検討の結果，水・メチルアルコールと塩化メ チレンの場合, $\mathrm{AD}$ および分解物が塩化メチレン層に分 配されること，水・メチルアルコールとへキサンの場合 には $\mathrm{AD}$ のタ一キサン層に分配されること, 有機溶媒中 の $\mathrm{AD}$ は $0.1 \mathrm{~N}$ 水酸化ナトリウム溶液で抽出できるこ と, 有機溶媒中の CM-I は希塩酸で抽出されないことが わかった. 水・メチルアルコール中の $\mathrm{AD}$ の抽出に塩化 メチンンを用いた場合，抽出率はへキサンよりもわずか よかったが妨害物をよけいに抽出することとアルカリ液 と分配する場合へキサンのほうが分液が良好だったた め, $\mathrm{AD}$ の抽出にはへキサンを使用した。

土畩および水試料の場合は, 液液分配によるクリーン アップのみで対象化合物の定量を妨害するピークは認め られなかったが，作物の場合，分解物の定量を妨害する ピークが認められたので，薄層クロマトグラフによるク リーンアップを検討した．薄層板は各化合物のバンドを 容易に切り取ることができるアルミシート（メルク製シ リカゲル Art. 5554) を使用した. クロロホルム/アセト ン=8/2）を用いた場合分解物と妨害物の分離がよかっ 
Table 2 Retention time $\left(l_{\mathrm{R}}\right)$ of AD and its decomposed compounds by HPLC.

\begin{tabular}{|c|c|c|c|c|}
\hline Column & Compound & Mobile phase & $t_{\mathrm{R}}(\min )$ & $\begin{array}{c}\text { Resolution of } \\
\text { CM-II \& CM-III }\end{array}$ \\
\hline \multirow{8}{*}{$\begin{array}{l}\text { Micropak } \\
\mathrm{Si}-10\end{array}$} & $\mathrm{AD}$ & $0.5 \% \mathrm{MeOH} / \mathrm{CH}_{2} \mathrm{Cl}_{2}$ & 4.6 & \\
\hline & $\mathrm{CM}-\mathrm{I}$ & & 22.4 & \\
\hline & CM-II & & 6.4 & \\
\hline & CM-III & & 7.5 & 1.3 \\
\hline & $\mathrm{AD}$ & $1.5 \% \mathrm{MeOH} / \mathrm{CH}_{2} \mathrm{Cl}_{2}$ & 3.9 & \\
\hline & $\mathrm{CM}-\mathrm{I}$ & & 7.4 & \\
\hline & $\mathrm{CM}-\mathrm{II}$ & & 4.4 & \\
\hline & CM-III & & 4.8 & 0.3 \\
\hline \multirow{8}{*}{$\begin{array}{c}\text { Micropak } \\
\text { CN-10 }\end{array}$} & $\mathrm{AD}$ & $50 \%$ Hexane $/ \mathrm{CH}_{2} \mathrm{Cl}_{2}$ & 2.9 & \\
\hline & CM-I & & 23.4 & \\
\hline & CM-II & & 8 & \\
\hline & CM-III & & 9.8 & 1.5 \\
\hline & $\mathrm{AD}$ & $\mathrm{CH}_{2} \mathrm{Cl}_{2}$ & 1.9 & \\
\hline & $\mathrm{CM}-\mathrm{I}$ & & 3.8 & \\
\hline & CM-II & & 2.4 & \\
\hline & CM-III & & 2.5 & 0.3 \\
\hline Micropak & $\mathrm{AD}$ & $30 \% \mathrm{H}_{2} \mathrm{O} / \mathrm{MeOH}$ & 6.6 & \\
\hline \multirow[t]{3}{*}{$\mathrm{CH}-10$} & $\mathrm{CM}-\mathrm{I}$ & $40 \% \mathrm{H}_{2} \mathrm{O} / \mathrm{MeOH}$ & 6.5 & \\
\hline & CM-II & " & 5.5 & \\
\hline & CM-III & " & 5.5 & 0 \\
\hline \multirow{7}{*}{$\begin{array}{l}\text { Hitachi-gel } \\
\quad \# 3010\end{array}$} & $\mathrm{AD}$ & $\mathrm{MeOH}$ & 8.4 & \\
\hline & CM-I & & 4.2 & \\
\hline & $\mathrm{CM}-\mathrm{II}$ & & 5.6 & \\
\hline & CM-III & & 5.6 & 0 \\
\hline & $\mathrm{AD}$ & $10 \% \mathrm{H}_{2} \mathrm{O} / \mathrm{MeOH}+0.2 \% \mathrm{NH}_{4} \mathrm{OH}$ & 3.0 & \\
\hline & CM-II & $10 \% \mathrm{H}_{2} \mathrm{O} / \mathrm{MeOH}$ & 14.8 & 0 \\
\hline & CM-III & & 14.8 & \\
\hline \multirow{4}{*}{ 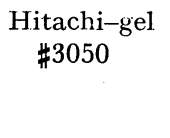 } & $\mathrm{AD}$ & $50 \% \mathrm{H}_{2} \mathrm{O} / \mathrm{MeOH}$ & 3.4 & \\
\hline & CM-I & & 8.6 & \\
\hline & CM-II & & 9.4 & 0.23 \\
\hline & CM-III & & 10.0 & \\
\hline
\end{tabular}

Table 3 Comparison of extractability from soil.

\begin{tabular}{ccc}
\hline \multirow{2}{*}{ Solvent } & \multicolumn{2}{c}{ Extractability (\%) } \\
\cline { 2 - 3 } & ADS & CM-I, II, III \\
\hline $\mathrm{MeOH}$ & $90-95$ & $85-95$ \\
$\mathrm{MeOH} / \mathrm{H}_{2} \mathrm{O} / \mathrm{EtOAc}$ & $85-90$ & $85-90$ \\
$2: 2: 1$ & & \\
$\mathrm{MeOH} / \mathrm{H}_{2} \mathrm{O}$ & $85-90$ & $90-95$ \\
$1: 1$ & & $90-95$ \\
$0.1 \mathrm{~N} \mathrm{~N}_{4} \mathrm{Cl} / \mathrm{MeOH}$ & $90-96$ & 9 \\
$1: 4$ & & \\
\hline
\end{tabular}

た.この溶媒系では CM-II と III の $R f$ は近似してい るが高速液体クロマトグラフィーの場合, CM-II と III を同時に切り取り抽出し，カラムで分離する方法を採用
した.しかし，紫外吸収スペクトル法の場合には CMII と III の分離を完全にすることが必要であったので, ベンゼンー酢酸エチル（10:3）の溶媒系を用いた。

\section{5. ガスクロマトグラフ定量用の誘導体の合成}

$\mathrm{AD}$ および分解物はガスクロマトグラフに注入した場 合, 熱により分解したり, 電子捕獲型検出器 (ECD) に 対する感度が不足するため, そのままの形では残留分析 に適用できなかったので，誘導体の合成を検討した。

1) $\mathrm{AD}$

ヘキサンを溶媒として無水トリフルオロ酢酸と室温で 反応させて得られた誘導体はガスクロマトグラフ中で十 分な感度を示さなかったことから, 熱分解しているもの と推定された. アリル基に臭素を付加させることを目的 として合成した誘導体もガスクロマトグラフの中で熱分 


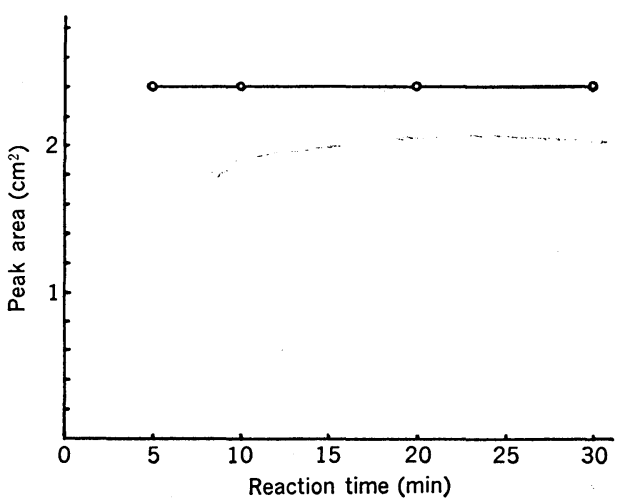

Fig. 3 Effect of reaction time on chlorination of AD.

$\mathrm{AD}: 50 \mu \mathrm{g}, \mathrm{NCS}$ : $50 \mathrm{mg}$.

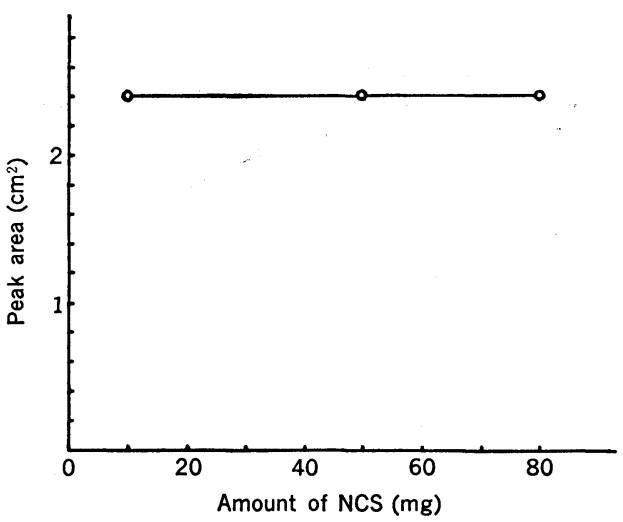

Fig. 4 Effect of amount of NCS on chlorination of AD.

$\mathrm{AD}: 50 \mu \mathrm{g}$, Reaction time: $10 \mathrm{~min}$.

解を起こした。 $N$-ブロモスクシンイミドとの反応は定 量性に乏しく，しかむ生成物のガスクロマトグラムはピ 一クの形状が悪かった. これに対して $N$-クロロスクシ ンイミド (NCS) との反応で得られた塩素付加体は, 熱 に安定であり ECD にも十分な感度を示した．塩素化の 条件を決めるために NCS の添加量, 反応時間について 検討した. 結果を Fig. 3 および Fig. 4 に示す.なお この実験を甜菜葉 $100 \mathrm{~g}$ を使用した場合でも同じ結果が 得られた。これらの結果から，NCS の添加量拈よび反 応時間はとくに単密に設定する必要はないが，本報では NCS $50 \mathrm{mg}$, 反応時間 10 分とした. 反応は定量的であ り $0 \sim 1.0 \mathrm{ppm}$ の範囲に拈いて, ADS の量とピーク面 積の関係線は直線が得られた。 また $40 \mu \mathrm{g}$ の $\mathrm{AD}$ を用 いて 6 回のくり返し実験を行なって再現性を検討した結
果，変動係数は $5.8 \%$ であり，十分実用性があることが わかった。

2) CM-I

CM-I の誘導体はいろいる考光られが，無水トリフ ルオロ酶酸 (TFAA) と反応させて得られた誘導体は ECD に対する感度も良好であったので，この他の誘導 体についてはとくに検討は行なわなかった．この場合， 溶媒として $n$-へキサン, 温度は室温とし，TFAA の添 加量を $0.2 \mathrm{ml}$ と $0.5 \mathrm{ml}$, 反応時間を $5 \sim 60$ 分の間で 検討した結果，TFAA の量は $0.2 \mathrm{ml}$ で十分であり，反 応時間は 5 10 分がよかった。 反応時間が 30 分以上に なると，副成分を生じピークがブロードになり，濃度と ピーク面積との間に直線関係が得られなくなった．以上 の結果, 反応条件として $n$-ヘキサン, 室温, TFAA の 添加量 $0.2 \mathrm{ml}$, 反応時間 10 分とした. 反応は定量的で あり，感度もきわめてよいが, 定量範囲は $0.1 \sim 0.5 \mathrm{ppm}$ と ADS の場合より狭かった。

3） CM-II および III

現在実用性のある誘導体が得られていないので, CMII および III についてはガスクロマトグラフによる定量 はできない。

\section{6. 検出限界および回収率}

1）高速液体クロマトグラフ法

各化合物それぞれ $10 \mathrm{ng}$ を注入したとき，ピーク高約 $5 \mathrm{~mm}$ の明瞭なピークが認められたので，これを最小検 出量とした。試料积取量を $100 \mathrm{~g}$, 最終液量を $1 \mathrm{ml}$, 注 入量を $10 \mu \mathrm{l}$ とした場合, 検出限界は $0.01 \mathrm{ppm}$ であ り，十分実用的であることがわかった。

2）ガスクロマトグラフ法

ADS および CM-I の最小検出量はそれぞれ $0.08 \mathrm{ng}$ $0.04 \mathrm{ng}$ であった。試料 $100 \mathrm{~g}$ を用いて最終液量を 25 $\mathrm{ml}$ とし，この液 $2 \mu \mathrm{l}$ をガスクロマトグラフに注入して いるので，検出限界は ADS で $0.01 \mathrm{ppm}, \mathrm{CM}-\mathrm{I}$ で $0.005 \mathrm{ppm}$ である.

3）紫外吸光光度法

ADS を希アルカリ溶液で測定した場合, 液量 $15 \mathrm{ml}$ で， $5 \mathrm{~cm}$ 角形セルを使用すると $1 \mu \mathrm{g}$ の透過率は $95 \%$ で，明らかに吸収帯が認められたので $1 \mu \mathrm{g}$ を最小検出 量とした. CM-I はメチルアルコール中で同様に $1 \mu \mathrm{g}$ を最小検出量とした．CM-II および III は吸光係数が 小さいことと吸収帯が短波長側にあるため，95\% の透 過率を得るために $3 \mu \mathrm{g}$ を必要としたので， $3 \mu \mathrm{g}$ を最小 検出量とした.

土塨および作物に ADS および分解物を添加して分析 し回収率 $(n=2)$ を求めた結果を Table $4 ， 5$ に示す. 
Table 4 Percent recoveries of each fortified compound in soil by HPLC.

\begin{tabular}{llccc}
\hline \multicolumn{1}{c}{ Soil } & Compound & $\begin{array}{c}\text { Sample } \\
\text { weight }(\mathrm{g})\end{array}$ & $\begin{array}{c}\text { Concentration } \\
(\mathrm{ppm})\end{array}$ & $\begin{array}{c}\text { Recovery* } \\
(\%)\end{array}$ \\
\hline Nagano & ADS & 30 & 0.225 & 85 \\
(humas volcanic ash, & CM-I & 30 & 0.225 & 87 \\
loam) & CM-II & 30 & 0.225 & 88 \\
& CM-III & 30 & 0.225 & 90 \\
\hline Mie & ADS & 30 & 0.225 & 94 \\
(sandy loam) & CM-I & 30 & 0.225 & 90 \\
& CM-II & 30 & 0.225 & 87 \\
& CM-III & 30 & 0.225 & 90 \\
\hline Aichi & ADS & 30 & 0.225 & 88 \\
(sandy loam) & CM-I & 30 & 0.225 & 89 \\
& CM-II & 30 & 0.225 & 92 \\
& CM-III & 30 & 0.225 & 92 \\
\hline
\end{tabular}

* Values are the average of duplicates.

Table 5 Percent recoveries of each fortified compound in crop by HPLC.

\begin{tabular}{|c|c|c|c|c|}
\hline Crop & Compound & $\begin{array}{c}\text { Sample } \\
\text { weight }(g)\end{array}$ & $\begin{array}{l}\text { Concentration } \\
(\mathrm{ppm})\end{array}$ & $\begin{array}{c}\text { Recovery* } \\
\left(\begin{array}{l}0 \\
( \\
0\end{array}\right)\end{array}$ \\
\hline \multirow{4}{*}{$\begin{array}{l}\text { Sugar beet } \\
\text { (root) }\end{array}$} & ADS & 100 & 0.2 & 87 \\
\hline & $\mathrm{CM}-\mathrm{I}$ & 100 & 0.2 & 82 \\
\hline & $\mathrm{CM}-\mathrm{II}$ & 100 & 0.2 & 78 \\
\hline & CM-III & 100 & 0.2 & 78 \\
\hline \multirow{4}{*}{$\begin{array}{l}\text { Sugar beet } \\
\text { (top) }\end{array}$} & ADS & 100 & 0.2 & 90 \\
\hline & CM-I & 100 & 0.2 & 92 \\
\hline & $\mathrm{CM}-\mathrm{II}$ & 100 & 0.2 & 79 \\
\hline & CM-III & 100 & 0.2 & 84 \\
\hline \multirow{4}{*}{ Soybean } & ADS & 50 & 0.2 & 92 \\
\hline & $\mathrm{CM}-\mathrm{I}$ & 50 & 0.2 & 82 \\
\hline & $\mathrm{CM}-\mathrm{II}$ & 50 & 0.2 & 76 \\
\hline & CM-III & 50 & 0.2 & 76 \\
\hline \multirow{4}{*}{ Onion } & ADS & 100 & 0.2 & 86 \\
\hline & $\mathrm{CM}-\mathrm{I}$ & 100 & 0.2 & 88 \\
\hline & $\mathrm{CM}-\mathrm{II}$ & 100 & 0.2 & 78 \\
\hline & CM-III & 100 & 0.2 & 76 \\
\hline \multirow{4}{*}{ Potato } & ADS & 100 & 0.2 & 86 \\
\hline & $\mathrm{CM}-\mathrm{I}$ & 100 & 0.2 & 82 \\
\hline & CM-II & 100 & 0.2 & 77 \\
\hline & CM-III & 100 & 0.2 & 75 \\
\hline \multirow{4}{*}{ Cabbage } & ADS & 100 & 0.2 & 93 \\
\hline & $\mathrm{CM}-\mathrm{I}$ & 100 & 0.2 & 89 \\
\hline & CM-II & 100 & 0.2 & 80 \\
\hline & CM-III & 100 & 0.2 & 78 \\
\hline \multirow{4}{*}{ Carrot } & ADS & 100 & 0.2 & 91 \\
\hline & $\mathrm{CM}-\mathrm{I}$ & 100 & 0.2 & 91 \\
\hline & $\mathrm{CM}-\mathrm{II}$ & 100 & 0.2 & 80 \\
\hline & CM-III & 100 & 0.2 & 78 \\
\hline
\end{tabular}

* Values are the average of duplicates. 

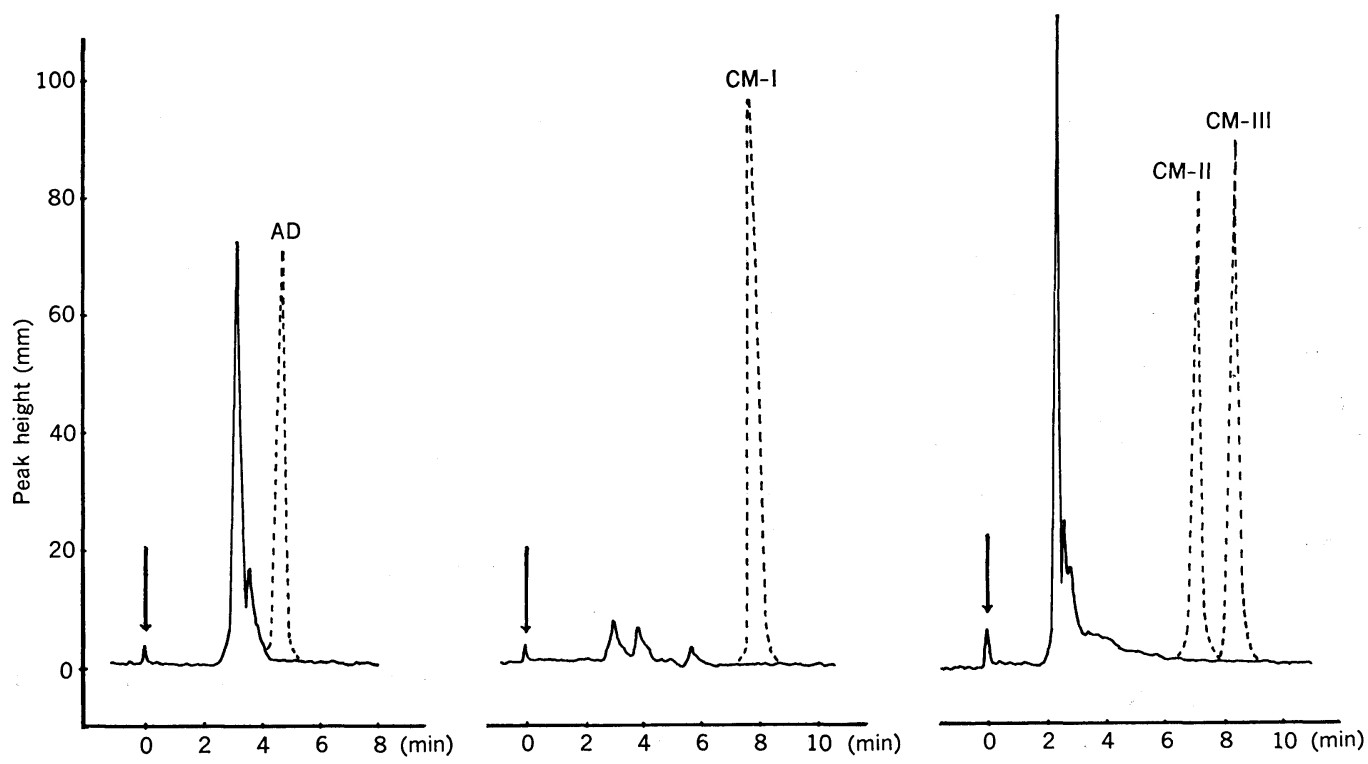

Fig. 5 Examples of liquid chromatogram.

Solid line: Unfortified sample (sugar beet top), Dotted line: Standard chemicals (200 ng), $\rightarrow$ : Injection.

Amount of sample $100 \mathrm{~g}$, final volume $1 \mathrm{ml}$; injected volume $10 \mu \mathrm{l}$.

いずれの場合もだいたい満足できる回収率が得られた. クロマトグラムの一例を Fig. 5 に示す.

\section{考察}

新選択性除草剮アロキシジムの植物における代謝研究

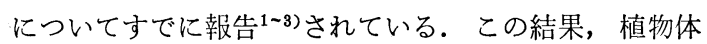
における代謝分解物はおむにフミノ体 (CM-I) でその他 は少量のオキサゾール体 (CM-II および CM-III) であ ったのでこれらの化合物を対象とした残留分析法を研究 した. 分析法として高速液体クロマトグラフ法, ガスク ロマトグラフ法拈よび紫外吸光光度法についてそれぞれ 検討した．これらの方法はいずれも共通して，フロキシ ジムの遊離体である $\mathrm{AD}$ と分解物 CM-I, II および III を液液分配によりまず分離し別々に定量した。土㙵の場 合, 薄層クロマトグラフィーによるクリーンアップはと くに必要なかったが, 作物の場合このクリーンアップが 必要だった. もっとも, 土㙵の種類によっては妨害が認 められることも考光られるので, その場合は, クロロホ ルム/アセトン $(8 / 2)$ の溶媒で上記したアルミシートを 使用した薄層クロマトグラフ操作が必要である. 分析操 作中に薄層クロマトグラフィーを行なう場合, この操作 による損失を補う意味で検量線の作成にも同じ操作を入 れたが，若干分析值が低くなることを無視できる場合は 薄層クロマトグラフ操作を省略した検量線を使用するこ
ともできる.

高速液体クロマトグラフ法, ガスクロマトグラフ法お よび紫外吸光光度法の 3 法について比較した場合, まず 紫外吸光光度法は簡便であるが, 妨害も受けやすく, 通 常収穫期の作物や同じ時期の土塨の分析等残留量の少な い場合には適用しにくいが, ADSのアルカリ溶液の吸収 帯は $287 \mathrm{~nm}, \mathrm{CM}-\mathrm{I}$ はメチルアルコール中で $289 \mathrm{~nm}$ と 比較的紫外部の長波長領域にあり分子吸光係数もそれぞ れ $2.0 \times 10^{4}, 1.6 \times 10^{4}$ であるので, 水系の残留分析や 植物葉面または土塨表面に処理したアロキシジムおよび CM-I の経時変化を調べる場合には紫外吸光光度法は便 利である. CM-I は特有な二つの極大吸収を 253 おょび $289 \mathrm{~nm}$ に示すので定性的にも便利である. ガスクロマ トグラフ法は $\mathrm{AD}$ および分解物ともに熱に不安定であ り, しかも ECD に対して感度が低いので誘導体の合成 が必要であった， AD の塩素付加体および CM-I のト リフルオロアセチル化体はともに ECD に対してきわめ て感度がよく，作物によってはさらに検出限界を下げる ことも可能であった. しかし CM-II および III につい ては十分に実用性のある誘導体を合成しえなかったため に, $\mathrm{AD}, \mathrm{CM}-\mathrm{I}, \mathrm{II}$ および III の 4 化合物の定量を必要 とする場合にはガスクロマトグラフ法は適用できない。 高速液体クロマトグラフ法はガスクロマトグラフ法のよ うに誘導体を合成する必要がなく, しかも $254 \mathrm{~nm}$ の固 
定波長の紫外線検出器でも 4 化合物を定量できる利点が あり検出限界も一応満足しうるものであり最も実用性の 高い定量法といえる. AD は極性溶媒中でシンーアンチ 型の異性体が存在するためメチルフルコールに溶解して 保存した後, その液を水・メチルアルコール系を移動相 とした高速液体クロマトグラフに注入すると必ず 2 ピー クが現われる。しかし，この異性体の存在は $n$-へキサ ンや塩化メチレンのような水不溶性の有機溶媒中では認 められない，すなわちフンチ型は存在しないため, 本法 では, 吸着型カラムを使用し, 少量のメチルアルコール を添加した塩化メチレンを移動相に使用した。なお，市 販の塩化メチレンのなかには安定郕としてメチルアルコ 一ルを添加してあるものと添加してないものがあるため 十分に注意する必要がある.

要約

作物，土塞および水系中に残留している除草郕アロキ
シジム (ADS) およびその代謝分解物 (CM-I, II および III）の分析方法を検討した. 高速液体クロマトグラフ 法, ガスクロマトグラフ法拉よび紫外吸光光度法の 3 法 を比較した結果，これら 4 化合物を定量するには高速液 体クロマトグラフ法が最も適していた。試料中の ADS および分解物はメチルアルコールで抽出し，液液分配に より ADS と分解物を分離したのち，クリーンアップし それぞれの化合物を紫外線検出器 $(254 \mathrm{~nm})$ 付高速液体 クロマトグラフで定量した。

\section{引用 文 献}

1) Y. Soeda, K. Ishihara, I. Iwataki \& H. Kamimura: J. Pesticide Sci. 4, 121 (1979)

2) Y. Hashimoto, K. Ishihara \& Y. Soeda: $J$. Pesticide Sci. 4, 299 (1979)

3) Y. Hashimoto, K. Ishihara \& Y. Soeda: $J$. Pesticide Sci. 4, 375 (1979) 